\title{
Pituitary gonadotropins regulate spermatogonial differentiation and proliferation in the rat ${ }^{+}$
}

\author{
JAGATPALA SHETTY, GOPAL K MARATHE, \\ SURESH RAMASWAMY and RAJAN R DIGHE* \\ Center for Reproductive Biology and Molecular Endocrinology, Indian Institute of Science, \\ Bangalore 560012, India
}

MS received 26 October 1995; revised 23 January 1996

\begin{abstract}
The relative regulatory roles of the pituitary gonadotropins, luteinizing hormone and follicle stimulating hormone in the spermatogonial proliferation has been studied using specific antibodies against these hormones in the immature rats. Immunoneutralization of luteinizing hormone for $\mathbf{7}$ days resulted in significant reduction in tetraploid cells and total absence of haploid cells, while there was a relative increase in the diploid population. This was also accomopanied by a decrease in spermatogonial proliferation as indicated by a decrease in $\left[{ }^{3} \mathrm{H}\right]$ thymidine incorporation into DNA by purified spermatogonia. Administration of follicle stimulating hormone a/s for 7 days also caused a significant decrease in the rate of spermatogonial proliferation. Withdrawal of follicle stimulating hormone led to a significant reduction in tetraploid and haploid cells. However interestingly, it failed to totally abolish the appearance of these cells. Administration of testosterone ( $3 \mathrm{mg} / \mathrm{day} / \mathrm{rat}$ ) for 2 days along with the gonadotropin a/s could partially reverse the effect on spermatogonial proliferation. It is concluded that (i) both luteinizing hormone and follicle stimulating hormone are involved in spermatogonial proliferation, (ii) lack of testosterone consequent of the neutralization of luteinizing hormone prevented the entry of spermatogonial cells into meiosis, (iii) testosterone may be involved in spermatogonia] proliferation providing a mitotic signal and (v) both follicle stimulating hormone and testosterone act synergistically and lack of any one of the hormones results in impairment of spermatogonial proliferation.
\end{abstract}

Keywords. Spermatogonial proliferation; gonadotropins; DNA synthesis; antibodies.

\section{Introduction}

Hormonal regulation of spermatogenesis, although a subject of many studies, has not been clearly understood (Steinberger 1971; Zirkin et al 1994). However, it can be concluded from the data available that the pituitary gonadotropins, luteinizing hormone (LH) and follicle stimulating hormone (FSH) are the principal regulators of spermatogenesis. Both these hormones regulate germ cell differentiation by regulating the function of the Sertoli cells, FSH directly and LH indirectly through testosterone. The Sertoli cells under the regulatory signals of FSH and androgens provide nutrients and differentiating signals (Je'gou and Sharpe 1993). It is still not clearly understood which differentiation steps in spermatogenesis are regulated by either gonadotropin although there are few reports demonstrating the sensitivity of certain phases of spermatogenesis for hormonal deprivation (Russell and Clermont 1977; Russell et al 1981) and binding of FSH to

\footnotetext{
${ }^{\dagger}$ A part of the data was presented at the 16th International Congress of Biochemistry and Molecular Biology, New Delhi, September 1994.

* Corresponding author(Fax. 091803341683; Email, rdighe@postoffice.iisc.ernet.in).
} 
seminiferous tubules appears to be stage dependent (Parvinen 1982). As for as early phase of spermatogenesis is concerned, there are some reports pertaining to the reinitiation of spermatogenesis in hypophysectomized rats under gonadotropic hormonal stimulation (Lostroh et al 1963; Chowdhury and Steinberger 1975; Chemes et al 1976, 1979). Apart from this knowledge, the precise role of individual gonadotropic hormones in spermatogonial proliferation and differentiation is poorly understood. The major blockade in elucidating these mechanisms is lack of suitable in vitro culture systems. Our group has been employing the strategy of using specific antibodies against gonadotropins to arrest gonadal differentiation in order to identify the LH and FSH dependent functions in the gonads (Shivshanker et al 1977; Sheela Rani et al 1978; Murty et al 1979; Moudgal and Dighe 1985; Vaishnav and Moudgal 1991). In the present study, an attempt has been made to study the role of gonadotropins in spermatogonial proliferation by employing gonadotropin antibodies.

\section{Materials and methods}

\subsection{Hormones}

Ovine LH and FSH used in the study were obtained from Prof. N R Moudgal, Indian Institute of Science, Bangalore and were purified and characterized as described earlier (Moudgal et al 1992). Rat LH and FSH used in the study were obtained from NIADDK.

\subsection{Gonadotropin antisera}

Antibodies were raised in the rabbits against ovine LH as described earlier (Madwaraj and Moudgal 1970). Ability of these antibodies to bind and neutralize rat LH was demonstrated by incubating $\left[{ }^{125} \mathrm{I}\right]$-labelled rat LH with these antibodies and determining binding. The retention of the antibody in circulation which is capable of binding to $\left[{ }^{125} \mathrm{I}\right] \mathrm{LH}$ was determined until $48 \mathrm{~h}$ after the administration of the antiserum. Further, the biological neutralization of rat LH was demonstrated by administering different amounts of antisera to the adult rats and determining the serum testosterone levels $3 \mathrm{~h}$ after the injection. In addition, antibodies were also administered to 21 day immature male rats for 5 to 7 days and decrease in the testicular weight was determined.

Antibodies were also raised against ovine FSH in the rabbits. To remove antibodies cross reacting with oLH, these antisera, were passed through oLH-Sepharose matrix and absence of LH cross reacting antibodies was demonstrated by lack of $\left[{ }^{125} \mathrm{I}\right] \mathrm{oLH}$ binding to the antisera while retaining the ability to bind to $\left[{ }^{125} \mathrm{I}\right] \mathrm{oFSH}$. Ability of these antibodies to bind rat $\mathrm{FSH}$ was demonstrated using $\left[{ }^{125} \mathrm{I}\right]$-labelled rat $\mathrm{FSH}$. Biological neutralization of rat FSH was demonstrated by administering different doses of antisera to 21 day old rats and determining the effect on testicular weight.

\subsection{Animals treatment}

Two separate groups of 21 day old immature rats $(n=30)$ were administered intraperitoneally $75 \mu \mathrm{l}$ of oLH a/s and $150 \mu 1$ of oFSH a/s for 7 days. The control groups included 20 rats treated with normal rabbit serum (NRS) in each group. The rats were sacrificed on the 8th day, and testes were removed before processing further. 


\subsection{Purification of germ cells}

The germ cells were purified by centrifugal elutriation according to the procedures of Meistrich et al (1981) and Bucci et al (1986) with several modifications in the rotor speed and the flow rates in order to obtain maximal purification of germ cells (Marathe et al 1995). Briefly, decapsulated testicular minces obtained from 30 rats were digested with collagenase $[0 \cdot 1 \%$ in Dulbecco's modified minimum essential medium (DMEM) containing $25 \mathrm{mM}$ Hepes, and DNAse $(25 \mu \mathrm{g} / \mathrm{ml})$ for $45^{\circ}$ and $32^{\circ} \mathrm{C}$ in a gyrating water bath $(150$ cycles/min)]. The cells were centrifuged, washed and resuspended in $\mathrm{Ca}^{2+} / \mathrm{Mg}^{2+}$ free phosphate buffered saline (PBS) containing $0 \cdot 1 \%$ glucose and $0 \cdot 2 \%$ bovine serum albumin (BSA) and approximately $2.5 \times 10^{9}$ cells were loaded into an elutriator rotor (Beckman JE6). The rotor speed was kept constant at $2650 \mathrm{rpm}$ and the flow rate was varied from approximately $6 \mathrm{ml} / \mathrm{min}$ to $40 \mathrm{ml} / \mathrm{min}$ and at each flow rate $150 \mathrm{ml}$ fractions were collected. The cells in each fraction were centrifuged at $100 \mathrm{~g}$ for $7 \mathrm{~min}$, washed once with BSA free buffer and resuspended according to the experimental protocol. An aliquot of each cell population was also fixed in $70 \%$ ethanol for DNA flow cytometry. The germ cell preparation, DNA staining and flow cytometric analysis were carried out according to the procedures standardized by Suresh et al (1992). The flowcytometer used in the study was obtained from Beckton-Dickinson (FAC Scan) and was equipped with an air-cooled 15 milliwatt argon-ion laser. The different populations of germ cells thus obtained based on the relative fluorescence intensities of their DNA content were expressed as $\mathrm{C}$ values using human peripheral blood leukocytes as the diploid standard (Suresh et al 1992). Approximately $10 \mu \mathrm{l}$ of the concentrated fraction was placed on the slide and a smear was made. The air-dried smears were immediately fixed in Bouin's fixative and stained in haematoxylin-eosin. The cells were identified according to the criteria followed by Meistrich et al (1973).

\subsection{Determination of $\left[{ }^{3} H\right]$ thymidine incorporation into different germ cell populations}

Elutriated fractions containing different populations of the germ cells $\left(5 \times 10^{6}\right.$ cells/ flask/ml) were incubated with $1 \mu \mathrm{Ci}$ of $\left[{ }^{3} \mathrm{H}\right]$ thymidine in Krebs'-Ringer bicarbonate medium containing $50 \mathrm{mM}$ Hepes $\left(\mathrm{pH} \mathrm{7.4)}\right.$ ) for $4 \mathrm{~h}$ at $32^{\circ} \mathrm{C}$. At the end of incubation period, unlabelled thymidine was added, DNA extracted according to the procedure of Sheela Rani and Moudgal (1978) and the radioactivity incorporated into DNA was determined and expressed as cpm/100 $\mu \mathrm{g}$ DNA.

The serum testosterone levels were measured by sensitive TRIA procedure routinely used in the laboratory (Mukku et al 1976). The assay sensitivities were $10 \mathrm{pg} /$ tube with intra- and inter-assay coefficients of variations of 6-8\%.

For histological study, the tissues were fixed in Bouin's fluid dehydrated in alcohol grades and paraffin sections were taken. The sections were stained with haematoxylin and eosin.

\section{Results}

\subsection{Characterization of LH and FSH antisera}

Passive immunization of 21 day old rats with different doses of $\mathrm{LH}$ a/s for 8 days 
prevented increase in the testicular weight seen in the control rats in a dose dependent manner with $75 \mu \mathrm{la} / \mathrm{s} / \mathrm{rat} /$ day causing more than $50 \%$ decrease in the testicular weight compared to the control. There was also a decrease in the serum testosterone levels $(0.96 \pm 0.3 \mathrm{~T} \mathrm{ng} / \mathrm{ml}$ in control and $0.035 \mathrm{~T} \mathrm{ng} / \mathrm{ml}$ in $\mathrm{LH} \mathrm{a} / \mathrm{s}$ treated group).

Passive immunization of 21 day old rats for 8 days with oFSH a/s, made free of LH antibodies by passing through LH affinity matrix, resulted in $40 \%$ decrease in the testicular weight. The serum testosterone level remained unchanged in these rats $(1.07 \pm 0.30 \mathrm{~T} \mathrm{ng} / \mathrm{ml}$ in control vs $1.05 \pm 0.21 \mathrm{~T} \mathrm{ng} / \mathrm{ml} \mathrm{in} \mathrm{FSH} \mathrm{a/s} \mathrm{treated} \mathrm{group).}$

\subsection{Effect of LH a/s on the germ cell pattern}

Administration of $\mathrm{LH}$ a/s to 21 day old rats resulted in severe damage to the seminiferous epithelium besides causing a marked reduction in testicular and tubular sizes and significant differences in the germ cell pattern. There was a relative increase in the spermatogonial population, decrease in the tetraploid cells and total absence of haploid population (figure 1B) as compared to control (figure 1A). This observation was also supported by DNA flow cytometry. As shown in figure 2, there was a relative increase in the peak corresponding to spermatogonia, decrease in the tetraploid cell peak and total absence of haploid peak as compared to day 28 control. This suggested that deprivation of $\mathrm{LH}$, which in turn causes a marked decrease in testosterone, results in slowdown of spermatogonial differentiation and prevents the cells from entering meiosis.

\subsection{Effect of FSH a/s on the germ cell pattern}

Administration of $\mathrm{FSH}$ a/s to 21 day old rats for seven days also caused severe damage to the seminiferous epithelium. There was a relative increase in the spermatogonial population similar to that seen in the $\mathrm{LH}$ a/s treated group (figures $1 \mathrm{C}$ and 2). However, both tetraploid and haploid cells were present in the testis, although the number of cells of each type was significantly reduced. This suggests that FSH a/s, while blocking differentiation of spermatogonia, did not block the meiosis per se and those cells which have already reached the advanced stage of meiosis did undergo meiosis and hence haploid cells could be seen in the testis.

\subsection{Purification and characterization of testicular germ cells}

Purification of testicular germ cells was achieved by centrifugal elutriation. Pure population of spermatogonia $(70 \%)$ was obtained at a flow rate $24.7 \mathrm{ml} / \mathrm{min}$ at a rotor speed of 2650 from the control rats. The purity of spermatogonial cells obtained from $\mathrm{LH} \mathrm{a} / \mathrm{s}$ and FSH a/s treated groups was $85-90 \%$ under similar conditions. The cells were identified by DNA flow cytometry and staining of the cell smears with haematoxylin and eosin. The characteristic germ cell pattern of the pre-elutriated germ cells and purity of each population obtained after elutriation, as determined by DNA flow cytometry, is shown in figure 3 . The fractions 3 and 4 show significant enrichment of spermatogonia. Presence of somatic cells such as Leydig cells and Sertoli cells were found in all the fraction and were always less than $10 \%$ of the total cell population (data now shown). 


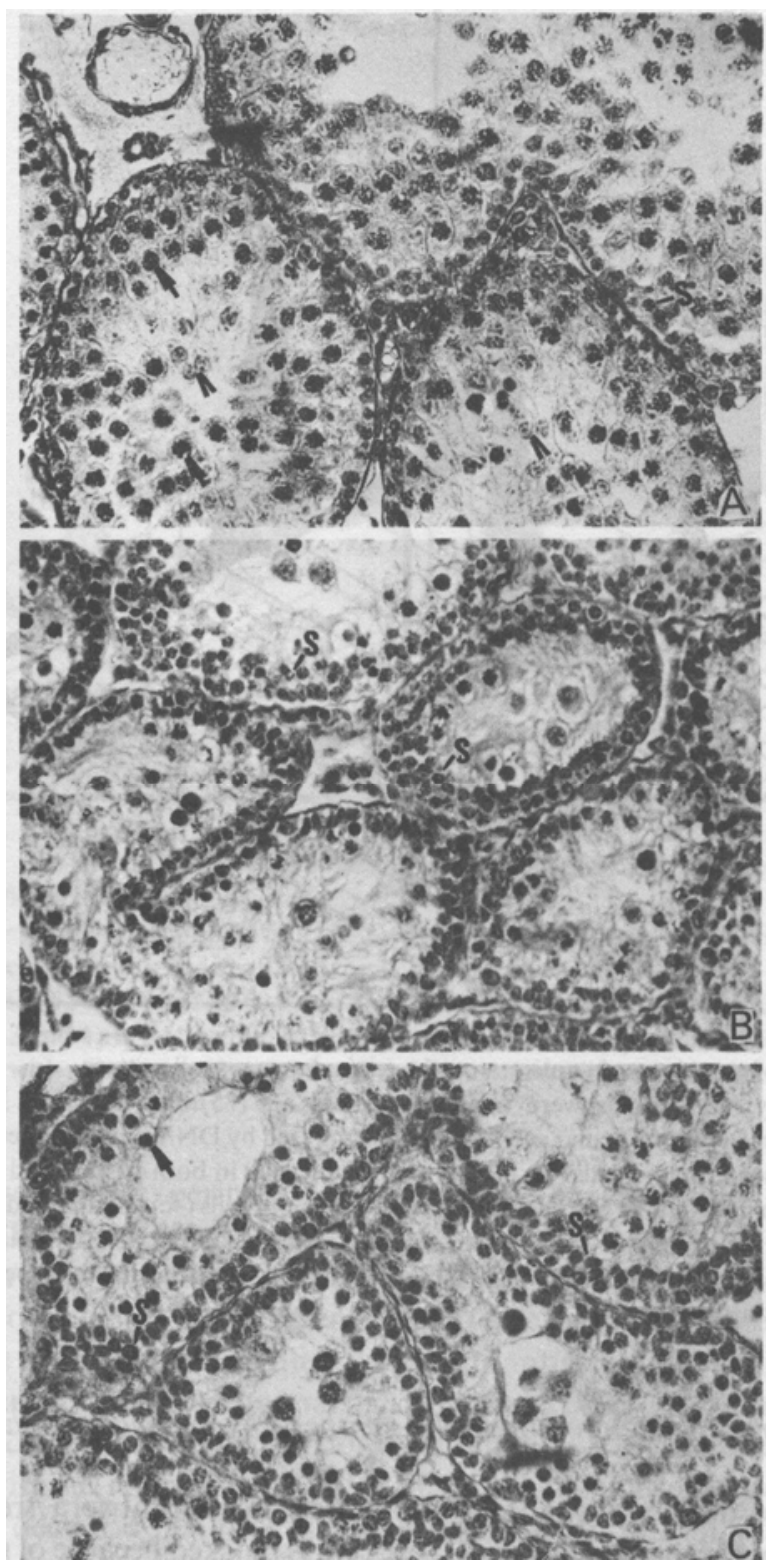

Figure 1. Histology of the testis treated with gonadotropin antisera.

Twenty one day old rats were treated with $\mathrm{LH} \mathrm{a} / \mathrm{s}$ (75 $\mu 1 /$ rat/day) and FSH a/s (150 $\mu 1 /$ rat/day). On the day 28 , testes were fixed in Bouin's fixative, embedded in paraffin and $4 \mu$ sections were cut. The sections were stained with haematoxylin and eosin. (A) Cross section of seminiferous tubules of control rat showing round spermatids (arrow heads) and pachytene spermatocytes (arrows) and spermatogonia(S). $(\times 450)$. (B) Cross section of seminiferous tubules of LH a/s treated rats showing a marked reduction in tubular diameter, the presence of only spermatogonia(S) and complete disappearance of pachytene spermatocytes and spermatids. $(\times 450)$. (C)Cross section of seminiferous tubules of FSH a/s treated rats showing a relative increase in spermatogonia(S) and a marked decrease in pachytene(arrow) and round spermatids. $(\times 450)$. 


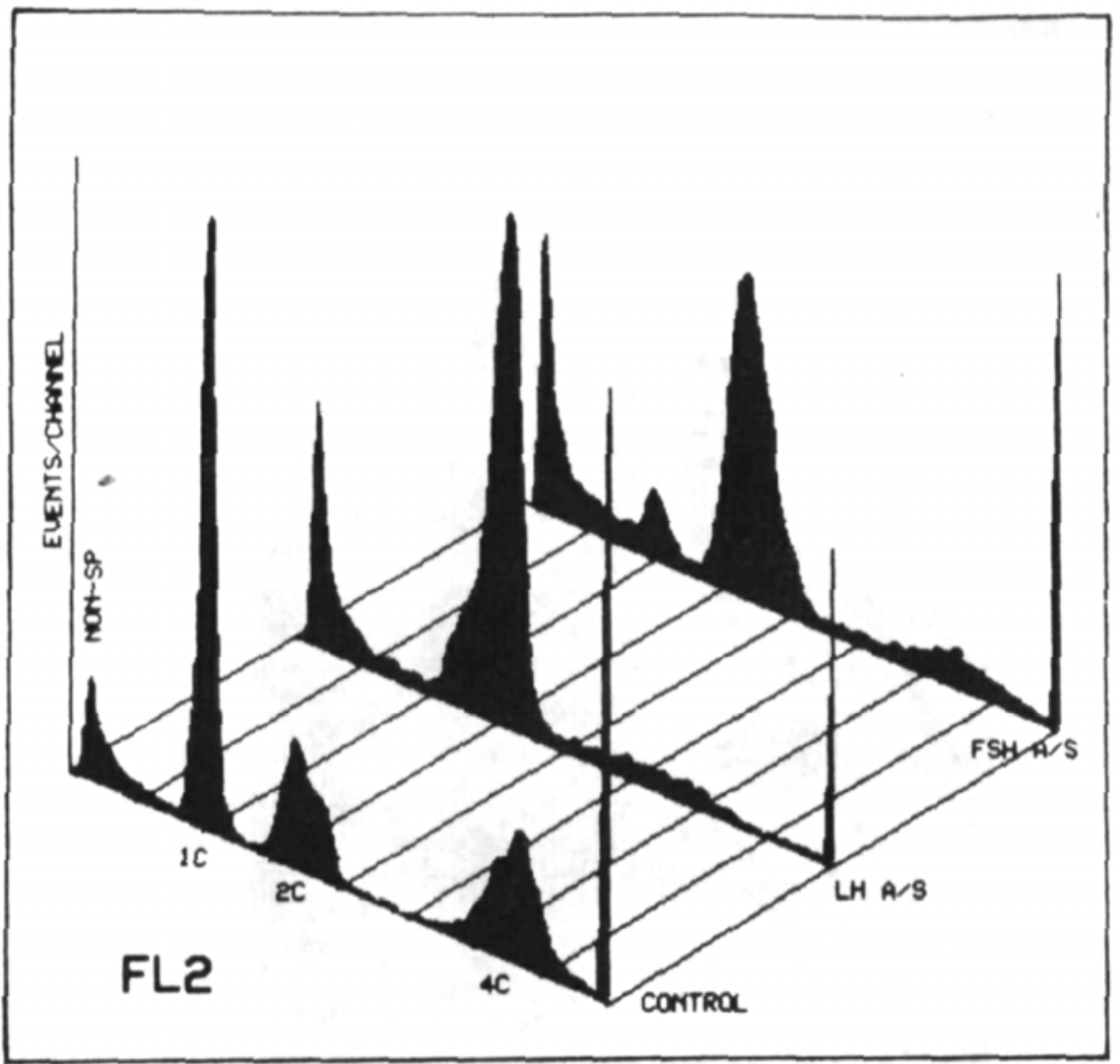

Figure 2. Effect of gonadotropin antisera on the testicular germ cell pattern.

Twenty one day old animals were treated with $\mathrm{LH}$ a/s (75 $\mu \mathrm{l} / \mathrm{rat} /$ day) and $\mathrm{FSH}$ a/s (150 $\mu 1 /$ rat/day). On day 28, testicular germ cells were analyzed by DNA flow cytometry. Note the relative increase in diploid cells (2c; mainly spermatogonia) in both $\mathrm{LH} \mathrm{a} / \mathrm{s}$ and FSH a/s treated group. Also note almost complete absence of tetraploid cells (4c) and haploid cells (1c) in $\mathrm{LH}$ a/s treated group. However, a small population of tetraploid and haploid cells is retained is retained in FSH a/s treated group though there is significant decrease in their population compared to the control.

\subsection{Effect of antisera treatment on the DNA synthesis by spermatogonia}

The relative increase in spermatogonial population in the antisera treated groups suggested that perhaps the differentiation of these cells is blocked because of gonadotropin deprivation. It was of interest to find out if the rate of DNA synthesis in these cells was affected. Hence spermatogonia enriched populations of germ cells were incubated with $\left[{ }^{3} \mathrm{H}\right]$ thymidine and the radioactivity incorporated into DNA was determined. As shown in the figure 4A, the cells purified from $\mathrm{LH} \mathrm{a}$ /s treated group showed significant decrease in the thymidine incorporation. The spermatogonia enriched populations from the control were contaminated with round spermatids which do not divide and do not incorporate thymidine appreciably (figure 5A). Hence if correction were to be employed for contamination of spermatids, the difference between control and $\mathrm{LH} \mathrm{a}$ as treated group is more enhanced. Similar results were obtained with FSH a/s treated 


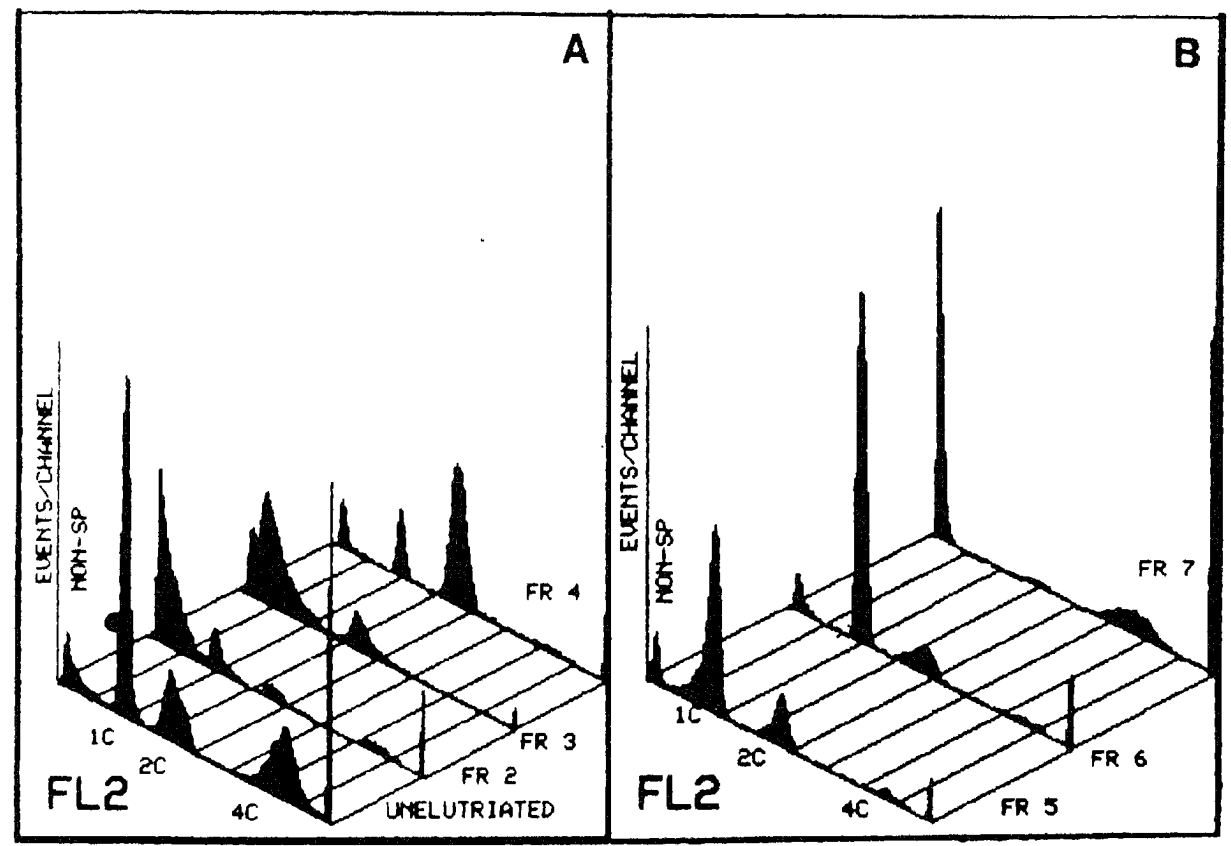

Figure 3. A typical DNA flow cytometric profile of the testicular germ cells from 28 day old rats purified by centrifugal elutriation.

A represents the fractions 2 to 4 (flow rates are $10.5 \mathrm{ml} / \mathrm{min}, 19.9 \mathrm{ml} / \mathrm{min}$ and $24.7 \mathrm{ml} / \mathrm{min}$ respectively, at a rotor speed of $2650 \mathrm{rpm}$ ) and $\mathbf{B}$ represents the fractions 5 to 7 (flow rates are $29.5 \mathrm{ml} / \mathrm{min}, 42.9 \mathrm{ml} / \mathrm{min}$ and $60.5 \mathrm{ml} / \mathrm{min}$ respectively, at a rotor speed of $2650 \mathrm{rpm}$ ). Note that fractions 3 and 4 are relatively enriched with diploid cells (2c; spermatogonia) and fraction 6 is enriched with spermatids (1c) and fraction 7 is enriched with tetraploid cells (4c).

group. In a separate experiment, spermatogonia enriched cells incorporated significantly less $\left[{ }^{3} \mathrm{H}\right]$ thymidine into DNA (figure $4 \mathrm{~B}$ ). The purity of each cell population used for determining thymidine incorporation is shown in figure $5 \mathrm{~B}$.

In order to find out if testosterone can reverse the effect of antisera on DNA synthesis, the animals were treated with each antisera and sacrificed after two days. A group of antisera treated animals also received $3 \mathrm{mg}$ testosterone/rat/day for two days. Radioactive thymidine incorporation into DNA was determined in the total cell population without any purification. In this experiment also antisera treatment caused a significant decrease in the $\left[{ }^{3} \mathrm{H}\right]$ thymidine incorporation. As shown in figure 6 , testosterone administration could partially, but significantly, restore $\left[{ }^{3} \mathrm{H}\right]$ thymidine incorporation (17-18\% compared to antisera treated groups).

\section{Discussion}

Hormonal regulation of spermatogenesis, although a subject of several studies, has not been clearly understood. It is generally believed that both LH and FSH are required for the initiation of spermatogenesis in the immature rats, the role of FSH in the adult rat spermatogenesis has not been unequivocally proved (Zirkin et al 1994). The major 


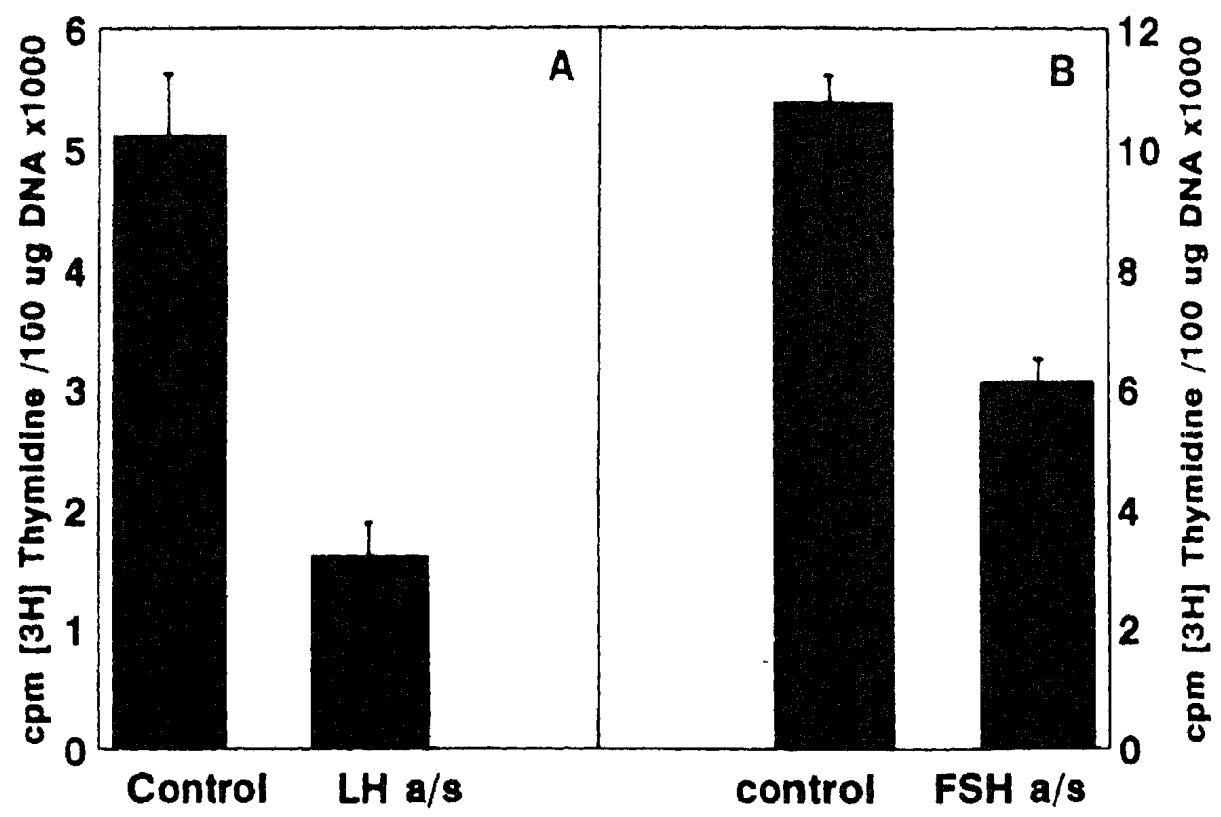

Treatment

Figure 4. Effect of gonadotropin deprivation on DNA synthesis by purified spermatogonia. Twenty one day old rats (30 each) were administered $\mathrm{LH} \mathrm{a} / \mathrm{s}(75 \mu \mathrm{l} / \mathrm{rat} /$ day) or FSH a/s (150 $\mu 1 /$ rat/day) for seven days. The NRS treated animals served as controls (20). The animals were sacrificed on 28th day, different population of germ cells were purified from the pooled cells obtained from individual group by centrifugal elutriation and spermatogonia enriched fraction was incubated with $\left[{ }^{3} \mathrm{H}\right]$ thymidine $(1 \mu \mathrm{Ci} / \mathrm{flask})$ and radioactivity incorporated into DNA was determined. Data presented are mean \pm SD of three flasks. The purity of the cell preparation used for the experiments is shown in figure 5. Control vs $\mathrm{LH} \mathrm{a} / \mathrm{s}: P<0 \cdot 001$. Control vs FSH a/s: $P<0 \cdot 001$.

handicap in understanding the roles of the hormones in this process is lack of suitable culture systems. We have been employing the alternate strategy of using antibodies to arrest spermatogenesis and identify the biochemical lesions in the germ cells.

Specific neutralization of individual gonadotropins by administration of antibodies to immature rats resulted in the arrest of spermatogenesis. Deprivation of either hormone caused inhibition of gain in the testicular weight. However, the effect of LH neutralization was different from that of FSH neutralization. While neutralization of both hormones caused an increase in relative proportion of the spermatogonial population, LH deprivation resulted, in a significant decrease in tetraploid cells and absence of haploid cells. In contrast, although FSH neutralization resulted in relative increase in the spermatogonial population, tetraploid cells and haploid cells were present in the testis. This suggested that lack of circulating LH affects the entry of cells into meiosis and hence no haploid cells are present in the testis. FSH perhaps does not affect the meiosis per se and hence the differentiation of those cells which have already entered meiosis is not affected and there were a few tetraploid and haploid cells. This is in perfect agreement of the conclusion drawn by Chemes et al (1979) who suggested that testosterone plays an important role in meiosis, while FSH may not be required for this process. Interestingly, the differentiation of the spermatogonia is dependent on both LH and FSH. Specific neutralization of each of these 


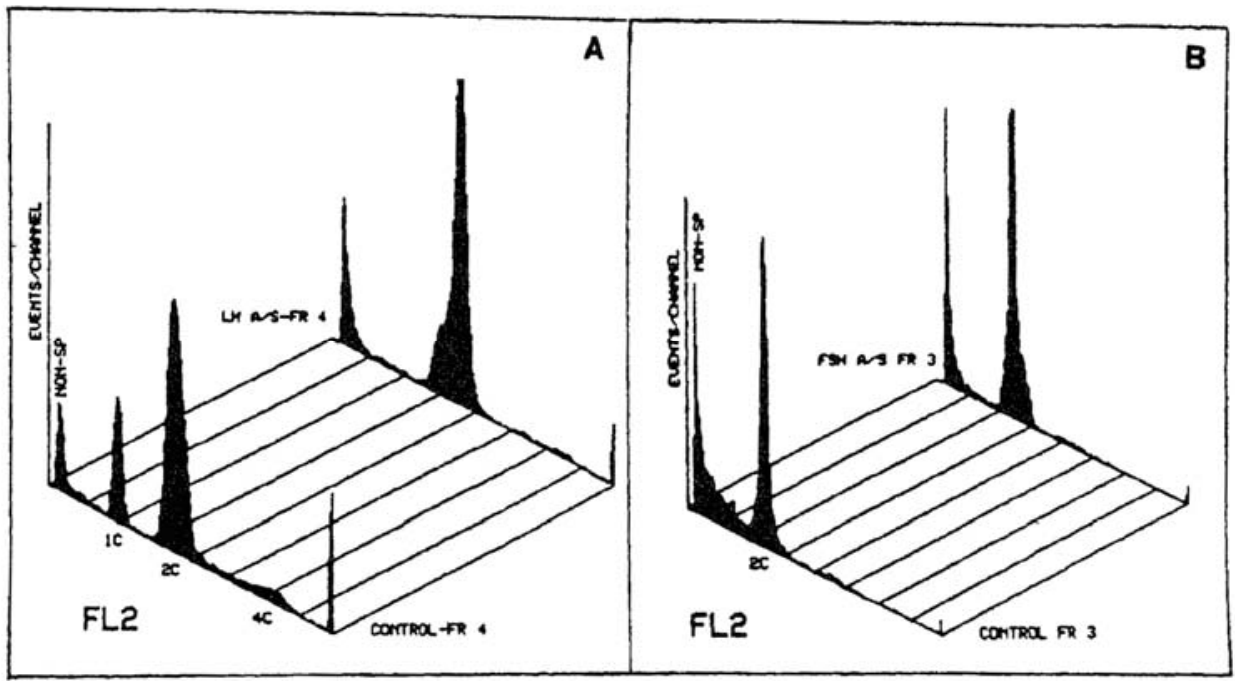

Figure 5. The purity of the populations used for $\left[{ }^{3} \mathrm{H}\right]$ thymidine incorporation.

Twenty one day old rats were administered $\mathrm{LH}$ a/s $(75 \mu \mathrm{l} / \mathrm{rat} / \mathrm{day})$ or $\mathrm{FSH}$ a/s (150 $\mu \mathrm{l} / \mathrm{rat} /$ day) for 7 days as described in figured 4. Animals were sacrificed on day 28 , and different population of germ cells were purified from pooled cells obtained from individual group by centrifugal elutriation. A represents the DNA flow cytometric profile of the spermatogonia(2c) enriched fraction ( $\mathrm{fr} 4$ ) of the $\mathrm{LH} \mathrm{a} / \mathrm{s}$ treated group with age match control (NRS treated). B represents the DNA flow cytometric profile of the spermatogonia(2c) enriched fraction (fr 3) of $\mathrm{FSH}$ a/s treated group with age match control.

\section{Treatment}

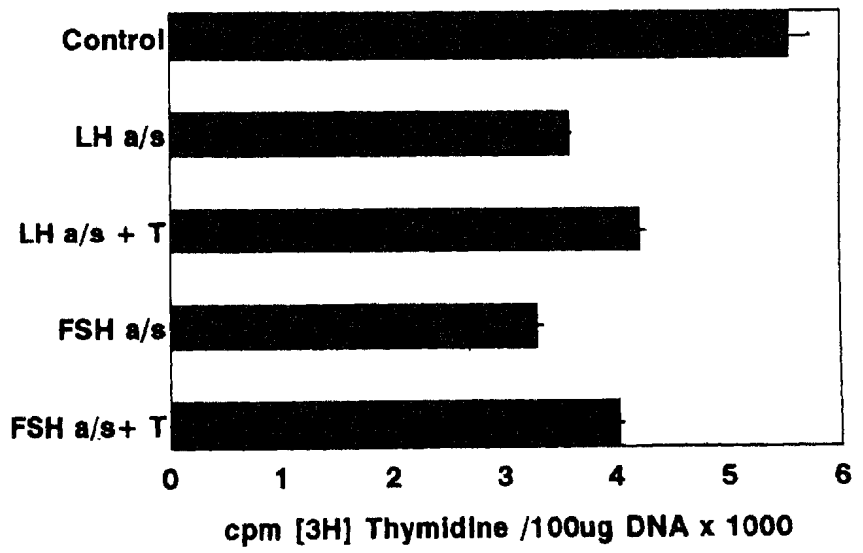

Figure 6. Effect of gonadotropin deprivation on DNA synthesis and partial reversal by the supplementation of testosterone.

Twenty one day old rats were administered $\mathrm{LH}$ a/s or FSH a/s for two days. Testosterone ( $3 \mathrm{mg} / \mathrm{rat} /$ day) was also administered intraperitoneally along with antisera to two separate groups of rats. The animals were sacrificed $24 \mathrm{~h}$ after the second injection and the rate of DNA synthesis in the total testicular germ cells in the pooled sample from the individual group without any purification was determined by estimating incorporation of radioactive thymidine into DNA. Each group included 4 rats. The data presented are mean $\pm \mathrm{SD}$ of three flasks. Control vs $\mathrm{LH} \mathrm{a} / \mathrm{s}: P<0 \cdot 001$. LH a/s vs LH a/s $+\mathrm{T}: P<0 \cdot 01$. Control vs FSH a/s: $P<0 \cdot 001$.FSHa/s vs FSH a/s $+\mathrm{T}: P<0 \cdot 01$. 
hormones resulted in the impairment of differentiation of spermatogonia. The block could be at the mitotic division of these cells. This is indicated by decrease in the $\left[{ }^{3} \mathrm{H}\right]$ thymidine incorporation by these cells into DNA. Lack of gonadotropic support perhaps results in the absence of mitotic signals from the Sertoli cells. Such mitotic signals have been predicted earlier (Bellve and Feig 1984). Simultaneous testosterone administration can partially reverse the effect of antisera. This suggests that testosterone may be involved in providing the mitotic signals. However the reason for only partial reversal, particularly in case of $\mathrm{LH}$ a/s administration, is not clear. Perhaps the intratesticular levels of testosterone have not attained the control levels. The importance of testosterone in the spermatogenic process is supported by studies in hypophysectomized or intact rats (Weinbauer and Nieschlag 1993). Provision of exogenous testosterone in the hypophysectomized rats prevented testicular involution and maintained spermatogenesis in a qualitative manner (Sun et al 1990). Similar findings were obtained in intact rats depleted of Leydig cells and supplemented with high doses of testoterone (Sharpe et al 1988). These observations plus the data with FSH a/s indicate that both FSH and testosterone act synergistically and lack of any one of the hormones results in the impairment of spermatogonial proliferation. A hypothesis suggesting that FSH and LH, presumably via stimulation of testosterone production act by the same mechanism has been put forward by Russel et al (1993). Involvement of FSH in spermatogonial proliferation has been suggested by Heckert and Griswold (1993) who showed that FSH receptor messenger RNA levels are highest in the stages XII-IV of spermatogenesis which encompass a number of spermatogonial division. The present study provides a direct proof for the role of FSH in the spermatogonial mitosis. The relative increase in the spermatogonial population following neutralization of gonadotropins suggests that proliferation and differentiation of these cells, which are coupled events, are slowed down. Consequently, the cells do not reach the stage from which they can enter meiotic prophase.

Earlier we have reported that the specific immunoneutralization of LH does not lead to the apoptotic cell death of the spermatogonial cells as opposed to the pachytene spermatocytes (Marathe et al 1995). This suggests that these cells are in a state of delayed differentiation under LH deprivation, and their function is restored once the testosterone is replenished. However the immunoneutralization of FSH lead to the apoptotic cell death of few spermatogonia as also that of the pachytene spermatocytes suggesting a role for FSH in the survival of spermatogonia and their function (J Shetty, G K Marathe and R R Dighe, unpublished results).

\section{Acknowledgements}

This work was supported by grants from the Department of Biotechnology, New Delhi and Rockefeller Foundation, USA.

\section{References}

Bellve A R and Feig L A 1984 Cell proliferation in the mammalian testis: biology of the seminiferous growth factor (SGF); Recent Prog. Horm. Res. 40 531-567

Bucci L R, Brock W A, Johnson T S and Meistrich M L 1986 Isolation and biochemical studies of enriched populations of spermatogonia and early primary spermatocytes from rat testes; Biol. Reprod. 34 195-206 
Chemes H E, Podesta E and Rovarola M A 1976 Action of testosterone, dihydrotestosterone, and 5-alpha androstane-3-alpha, 17-beta-diol on spermatogenesis of immature rats; Biol Reprod. 14 332-338

Chemes H E, Dym M and Raj H G M 1979 The role of gonadotropins and testosterone on initiation of spermatogenesis in the immature rat; Biol. Reprod. 21 241-249

Chowdhury A K and Steinberger E 1975 Effect of 5-alpha-reduced androgens on sex accessory organs, initiation and maintenance of spermatogenesis in the rat; Biol. Reprod. 12 609-617

Heckert L and Griswold M D 1993 Expression of the FSH receptors in the testis; Recent Prog. Horm. Res. 48 61-77

Je'gou B and Sharpe R M 1993 Paracrine mechanisms in testicular control; in Molecular biology of the male reproductive system (ed.) de Krester (New York: Academic Press) pp 271-301

Lostroh A L, Johnson R and Jordan C W Jr 1963 Effect of ovine gonadotropins and antiserum to interstitial cell-stimulating hormone on the testis of the hypophysectomized rat; Acta Endocrinol. 44 536-544

Madwaraj H G and Moudgal N R 1970 Hormonal control of gestation in the intact rat; Endocrinology 86 874-889

Marathe G K, Shetty J and Dighe R R 1995 Selective immunoneutralization of luteinizing hormone results in the apoptotic cell death of pachytene spermatocytes and spermatids in the rat testis; Endocrine 3 705-709

Meistrich M L, Bruce W R and Clermont Y 1973 Cellular composition of fractions of mouse testis cells following velocity sedimentation separation; Exp. Cell Res. 19 213-227

Meistrich M L, Longtin J, Brook W A, Grimes S R Jr and Mace M L 1981 Purification of rat spermatogenic cells and preliminary biochemical analysis of these cells; Biol. Reprod. 25 1065-1077

Moudgal N R and Dighe R R 1985 An immunological approach to study gonadotropin action at the cellular and molecular level; Biosci. Rep. 5 943-955

Moudgal N R, Ravindranath N, Murthy G S, Dighe R R, Aravindan G R and Martin F 1992 Long term contraceptive efficacy of vaccine of ovine Follicle stimulating hormone in male bonnet monkeys (Macaca radiata); J.Report. Fertil. 96 91-102

Mukku V R, Prahalada S and Moudgal N R 1976 Effect of constant light on nycthermal variations in serum testosterone in male Macaca radiata; Nature (London) 260 778-780

Murty G S R C, Sheela Rani C S, Moudgal N R and Prasad N R 1979 Effect of passive immunization with specific antiserum to FSH on the spermatogenic process and fertility of adult male bonnet monkey $(M$. radiata); J. Reprod. Fertil Suppl. 26 147-163

Parvinen M 1982 Regulation of the seminiferous epithelium; Endocrinol. Rev. 3 404-417

Russell L D and Clermont Y 1976 Degeneration of germ cells in normal, hypophysectomized and hormone-treated hypophysectomized rats; Anat. Rec. 187 347-366

Russell L D, Malone J P and Karpas S L 1981 Morphological pattern elicited by agents affecting spermatogenesis by disruption of its hormonal stimulation; Tissue Cell 13 369-380

Russell L D, Corbin T J, Bor K E, de Fraca L R, Grasso P and Bartke A 1993 Recombinant human follicle stimulating hormone is capable of exerting a biological effect in the adult hypophysectomized rat by reducing the numbers in degenerating germ cells; Endocrinology 133 2062-2070

Sharpe R M, Fraser H M and Ratnasooriya W D 1988 Assessment of the role of Leydig cell products other than testosterone in spermatogenesis and fertility in adult rats; Int. J. Androl. 11 507-523

Sheela Rani C S and Moudgal N R 1978 Studies on the follicular growth in the immature rat and hamster; Effect of a single injection of gonadotropin or estrogen on the rate of $\left[{ }^{3} \mathrm{H}\right]$-thymidine incorporation into ovarian DNA in vitro; Proc. Indian Acad. Sci. (Anim. Sci.) 87 41-51

Sheela Rani C S, Murty G S R C and Moudgal N R 1978 Effect of chronic neutralization of endogeneous FSH on testicular function in the adult male bonnet monkey-assessment using biochemical parameters; Int. J. Androl. 1 489-500

Shivashankar S, Prasad M R N, Thampson T N R V, Sheela Rani C S and Moudgal N R 1977 Effect of highly purified antiserum to FSH on testicular function in immature rats; Indian J. Exp. Biol. 15 845-851

Steinberger E 1971 Hormonal control of mammalian spermatogenesis; Physiol. Rev. 51 1-22

Sun Y T, Irby D C, Robertson D M and De Krester D M 1990 Quantitative cytological studies of spermatogenesis in intact and hypophysectomized rats: Identification of androgen-dependent stages; Endocrinology1271215-1223

Suresh R, Aravindan G R and Moudgal N R 1992 Quantitation of spermatogenesis by DNA flow cytometry: Comparative study among six species of mammals; J. Biosci. 17 413-419

Vaishnav M V and Moudgal N R 1991 Effect of specific deprivation of FSH or LH of testicular function of the adult rat; Indian J. Biochem. Biophys. 28 513-520 
Weinbauer G F and Nieschlag E 1993 Hormonal control of spermatogenesis; in Molecular biology of the male reporductive system (ed.) de Krester (New York; Academic press) pp 99-142

Zirkin B R, Awoniyi C, Griswold M D, Russell L D and Sharpe R M 1994 Is FSH required for adult spermatogenesis?; J. Androl. 15 273-276

Corresponding editor: RAGHAVENDRA GADAGKAR 